\title{
Management breaks the natural productivity-biodiversity relationship in forests and grassland: an opinion
}

\author{
E. D. Schulze ${ }^{1 *}\left(\mathbb{D}\right.$, O. Bouriaud ${ }^{2}$, U. Weber ${ }^{1}$, C. Roscher ${ }^{3}$, D. Hessenmoeller ${ }^{4}$, F. Kroiher $^{5}$ and P. Schall ${ }^{6}$
}

\begin{abstract}
Background: Two approaches mark the difference between the "ecological" and "agricultural" view of the biodiversity/ growth relation. In ecology the trend is averaged by taking monocultures of all species as baseline to evaluate mixtures. This contrasts the "agricultural" view focusing on the most productive species or species combination as baseline to evaluate mixtures. The present study investigates the change of highest rates (maximum) productivities in grasslands and forests with increasing plant (or tree) diversity, and compares these with the average response.

Methods: We base our analysis on existing published datasets relating the growth of plant stands (growth rate per land area) to the diversity on the same plot. We use a global dataset (Ellis et al. 2012 and MODIS-data, see Fig. 1), the grassland experiment in Jena (Buchmann et al. 2017), the regional study on forests in Romania and Germany by Bouriaud et al. (2016), and data from the German National Forest inventory (BWI 3, see Fig. 3). In all cases the average response of growth to changes in biodiversity as well as the boundary line of the maximum values was calculated.

Results: In both vegetation types a decreasing trend of maximum productivity with any added species emerges, contrasting the average trend that was positive in grassland, but absent in forests. The trend of maximum values was non-significant in grasslands probably due to the fact that not all combinations of species mixtures were available. In temperate forests, maximum productivity decreases significantly by about $10 \%$ in regional studies and by $8 \%$ at national scale with each added species. Maximum biomass per area was the same for managed and unmanaged conditions. A global assessment of NPP and biodiversity could also not confirm a general positive biodiversityproductivity relationship.

Conclusions: Managed grasslands and forests reach highest productivity and volumes at low diversity. Also globally we could not confirm a biodiversity effect on productivity. Despite this, for long-living organisms, such as trees, the incentive for land managers exists to reduce the risk of failure due to climate extremes and diseases by taking a loss in productivity into account and to actively maintain a mixture of species.
\end{abstract}

Keywords: Biodiversity, Productivity, Maximum rates, Land management, Forests, Grasslands

\section{Background}

Mankind faces an increasing number of conflicting demands for maintaining global integrity. There is the need for mitigating climate change, the demand for maintaining global diversity, and the necessity to supply an ever increasing amount of biomass for human needs of food, wood, energy and fiber. In this context, the observation that biomass production can be increased by increasing

\footnotetext{
* Correspondence: dschulze@bgc-jena.mpg.de

${ }^{1}$ MPI Biogeochemistry, Box 100164, 07701 Jena, Germany

Full list of author information is available at the end of the article
}

plant diversity is highly important. Hector et al. (1999) summarized the results from a European Grassland Experiment by the simple equation, namely that doubling plant diversity increases biomass production of grasslands by $20 \%$. However, despite an overwhelming confirmation of this observation from other ecosystems (Scherer-Lorenzen in Schulze et al. 2017), the acceptance by land-users in agriculture and forestry remains low. Monocultures remain the main source for food and fiber worldwide perhaps of conflicting interpretations of 


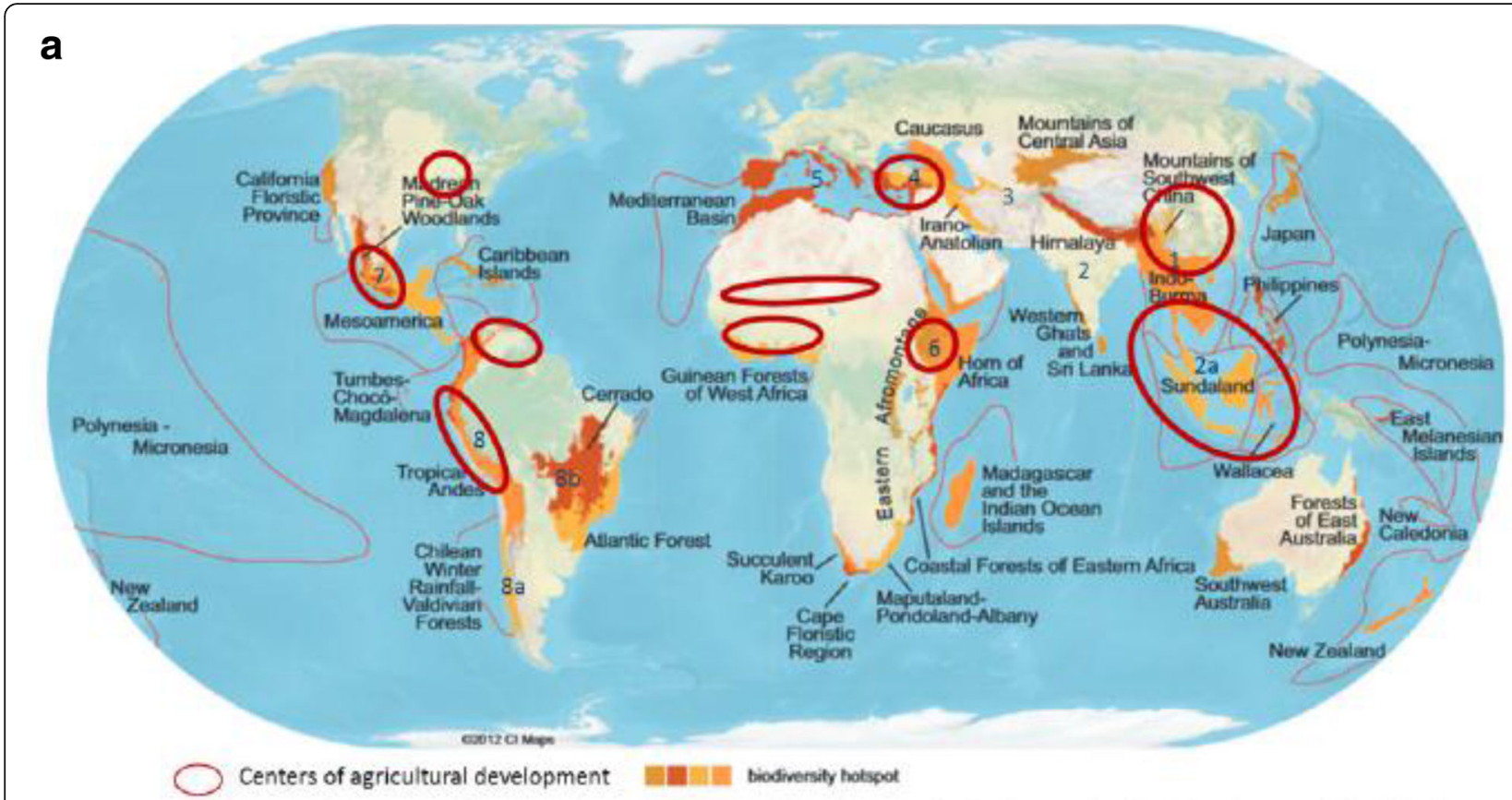

1-8 = Vavilov's centers of diversity: China (1); Indian subcontinent (2); Southeast Asia (2a); Central Asia (3); Turkey-Iran, fertile haif moon (4); Mediterranean area (5); Ethiopia (6); Mexico (7), Andes (8); the Chilean (8a) and Brazilian/ Paraguayan (8b) non-centers

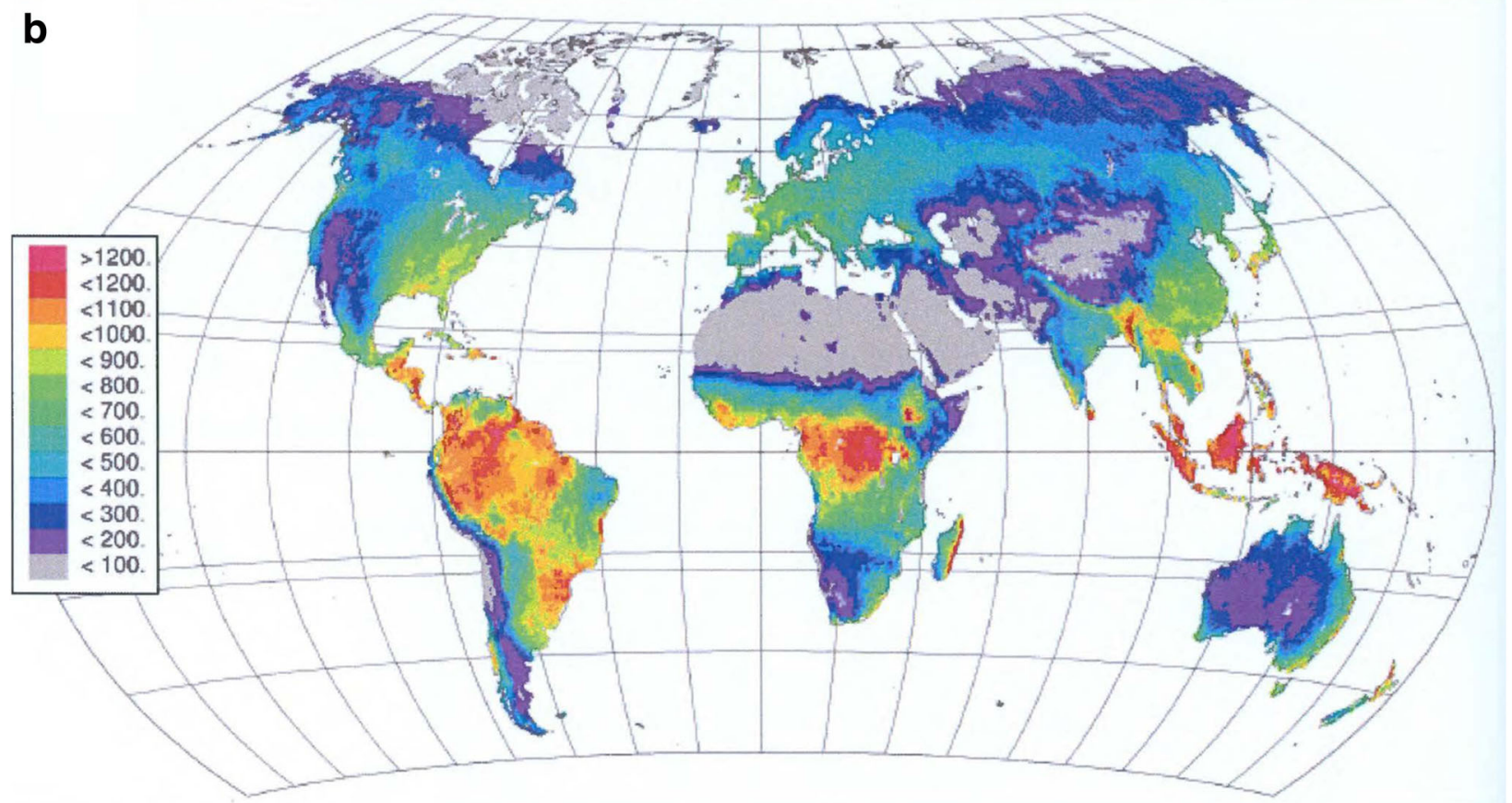

Fig. 1 a Global map of diversity and of the genetic centers for agricultural crops (Hilger et al. 2015). b Global map of Net Primary Production, NPP, in $\mathrm{gC} \cdot \mathrm{m}^{-2} \cdot \mathrm{yr}^{-1}$ (from Schulze et al. 2017, based on Cramer et al. 2001)

the same results, or because of practical reasons, since maintaining diversity can be very work-demanding.

In the following we try to explore the basis for these opposing views, namely the demand for increasing biomass production via diversity and the resilience by land- users to discard monocultures. In this process, we should be aware, that the relation between biomass production and diversity is not direct, but mediated by numerous parameters, including human management, and by variations in site conditions. In an initial step we will 
evaluate global distributions of diversity and productivity in order to re-inspect in a second step grassland and forest experiments.

\section{Methods}

In this study we re-asses existing data by Bouriaud et al. (2016), Buchmann et al. (2017), Schall et al. (2017) and Liang et al. (2016) specifically in terms of biodiversity effects. In the past, the productivity/diversity relations were studied with a focus on the average change of productivity with plant species numbers. In most cases, an increase with diversity was observed and interpreted by the effects of selection and complementarity (Loreau and Hector 2001). However, Schmidt et al. (2008) already pointed out that average (or 0.5 percentile) functions overestimate the diversity effects due to high numbers of monocultures in experimental assembles. In the present study, we try to overcome the problems of nonnormal distributions of data, by inspecting the maximum value or values of productivity at each level of species number, and we compare this function with the average diversity response. The statistical problem remains that the sample size changes with the level of species number, but taking the maximum values can avoid unwanted effects of management on maximum productivity.

\section{Results and Discussion}

\section{Global diversity and productivity}

Despite of a general trend with higher plant diversity in tropical and sub-tropical climates than in boreal zones, Hilger et al. (2015) show that biodiversity is not uniformly distributed in any climatic region (Fig. 1a). There are "hotspots" of diversity with unusually high species numbers, mainly of endemic plant species. However, even in the tropics there are regions of plant diversity as low as in boreal forest. In addition, there are genetic centers of origin (Vavilov centers) for agricultural crops. It is of interest to see, if the patterns, as observed by Hilger et al. (2015) emerge in global maps of productivity. Taking the global map of net primary production (NPP) of terrestrial ecosystems (Fig. 1b), the pattern of decreasing productivity with latitude remains, but, the regions with highest productivity in South America and Africa do not match the hotspots of diversity. Also, in the Mediterranean climate and in the temperate zone, NPP distribution does not match the diversity hotspots. The same discrepancy between plant diversity and productivity emerges with agricultural crops, which reach maximum rates in the temperate zones (West et al. 2010). However, agricultural cropping takes place on a different parcel of land than natural diversity, and can therefore not directly be compared.

The global patterns of diversity and NPP contain variations in numerous additional factors, such as soils, water and nutrient supply, and elevation, which could dim the diversity effect, and increase the variation. Thus, the relation between NPP and vascular plant diversity was investigated on 16,805 hexagonal grid cells (pixels of $\sim 7800 \mathrm{~km}^{2}$ ) for which the presently existing plant diversity (anthropogenic species richness) has been quantified (Ellis et al. 2012, Fig. 2). Diversity ranges between 0 and about 5000 vascular plant species per pixel, and the 10-year averages of mean annual NPP, as measured by Modis (https://e4ftl01.cr.usgs.gov/ MOLT/MOD17A3.055/, accessed 27 July 2017), reach $2500 \mathrm{gC} \cdot \mathrm{m}^{-2} \cdot \mathrm{yr}^{-1}$ (equivalent to about $50 \mathrm{t}$ dry weight $\mathrm{ha}^{-1} \cdot \mathrm{yr}^{-1}$ ). The data show a higher density of datapoints at low diversity. Cumulatively, $90 \%$ of the species number and about $90 \%$ of the total sum of NPP is reached at about $60 \%$ of maximum local diversity. The 0.5 percentile dots indicate that following an initial increase with diversity NPP remains constant or even decrease beyond 2500 species per pixel. Diversity levels > 2500 species per pixel represent the global hotspots of diversity (Additional file 1: Figure S1). Maximum NPP (0.9 percentile dots) saturates at the same level of diversity. The variation of NPP at each level of diversity is large, and increases with increasing species diversity. In fact, the variation of the 0.9 percentile value gets almost random at high diversity. Thus, high diversity does not enhance NPP beyond a certain level, and the contribution of global diversity hotspots for the global total of NPP appears to be low.

Obviously, the NPP-diversity relation is not linear across the range of diversity, where the global distribution of diversity is left-skewed towards low diversity. The increasing variation and the final decline of NPP with diversity may be explained by the fact, that many hotspots are located in alpine and semi-arid regions.

The relation of NPP and global diversity does not allow an assessment of the effects of a loss of species. The effect on NPP may be detrimental, if a dominant species is lost (e.g. Picea abies during forest decline by $\mathrm{SO}_{2}$ emissions). In this case NPP may collapse despite high diversity at the pixel level. On the contrary, if an auxiliary species is lost (e.g. Ulmus ssp., by Duch elm disease) there may be no effect on NPP. Therefore, in the following we try to separately assess the NPP productivity relations for grasslands and for forests at greater detail.

\section{Grasslands}

Grasslands have been the model system for studying the relation between NPP and diversity. Experimental systems were established by Tilman et al. (1996), by Hector et al. (1999), and by Weisser et al. (2017, the JenaExperiment) to avoid confounding effects of soils. Here we take the data of Buchmann et al. (2017) because they combine the data of the Jena-Experiment with data from surrounding semi-natural grasslands in the same year 


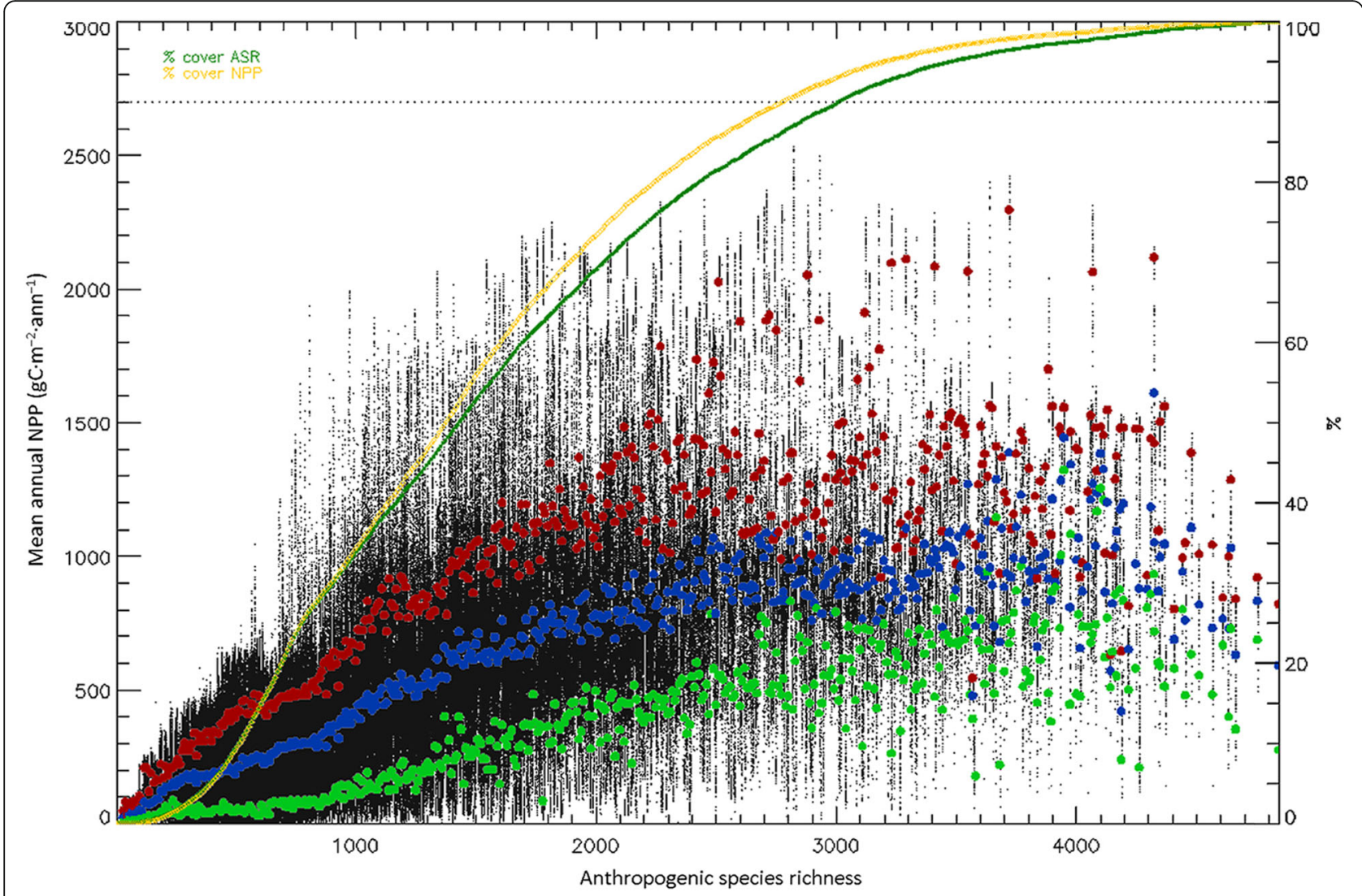

Fig. 2 Relations between mean annual NPP (10-yr average of Modis) and "anthropogenic species richness", which is the number of presently existing vascular plant species per grid cell of $\sim 7800 \mathrm{~km}^{2}$ (Ellis et al. 2012), including effects of human land use and land use change. The dots show 10 species averages along the $x$-axis, and the 0.1 (green), 0.5 (blue) and 0.9 (brown) percentiles along the NPP $y$-axis. The closed lines show the cumulative number of species as fraction of total species number (green line), and the cumulative NPP as fraction of total global NPP (yellow line)

(Fig. 3). Biomass is taken as measure for aboveground NPP in grasslands.

The data-cloud shows a significant increase of average biomass with increasing plant species number, explaining $21 \%$ of the variation. The increase is caused by a selection and by a complementarity effect (Loreau and Hector 2001). However, there is a tendency for more data points at low diversity (monoculture of each species as reference) than at high diversity, which may affect the slope of the $\mathrm{NPP} /$ diversity relation (Schmid et al. 2008). The analyses of Buchmann et al. (2017) of the mechanisms of this positive relation shows that biomass-production via diversity is mainly determined by the availability of nitrogen, where nitrogen is supplied by legumes. In managed grasslands nitrogen is added by fertilizer.

Neither the grassland experiments nor the ambient semi-natural grasslands contain all possible species combinations. Therefore we try to assess the diversity effect in a reverse approach, by viewing selectively the maximum rates at each density level, even though the problem exists that not all species combinations contain the species of highest productivity (a kind of negative

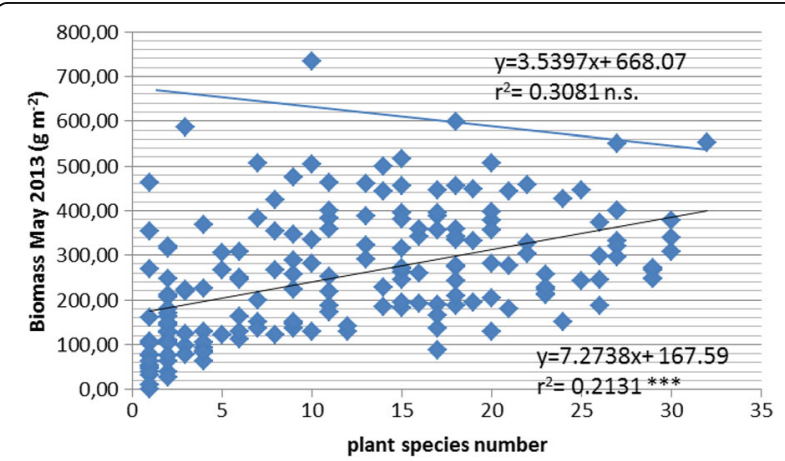

Fig. 3 Relations between biomass in May 2013 and plant species diversity in the Jena Experiment and semi-natural surrounding grasslands. Biomass is taken as measure for aboveground NPP in grasslands (Buchmann et al. 2017). The lower line and the lower equation describes the average response based on all data-points, while the upper line and equation describes the response of biomass with plant species number of the 5 maximum values at 2, 10, 18, 27 and 32 species 
selection effect). The highest biomass values (5\% percentile) shows decreasing biomass with diversity $\left(r^{2}=\right.$ 0.31 ), but the number of available data is too small to be significant. The maximum biomass was observed at 10 species mixtures. Biomass of a single species in a 3 species mixture may be as high as the species mixture of 17 and more species, as known from fertilized meadows (Buchgraber and Grindl 2004). The data set does not contain a high-yielding monoculture. The average loss in maximum productivity is $0.5 \%$ loss with each absent species, but it remains unclear, if the initial response is linear. A positive effect of species mixtures apparently remains at low species numbers, most likely by over-yielding.

The two approaches mark the main difference between the "ecological" view of the average trend taking monocultures of all species as baseline, and the "agricultural" view focusing on highest productivity. Also, agriculturist would be interested to know, which features result in highest biomass production. We will not evaluate the two approaches but point at genuine differences. In the case of the Jena-Experiment, the highest NPP was reached by Onobrychis viciifolia (esparsette) as dominant species with few additional subdominant species. Onobrychis also contributes to a large extent to the high NPP at experimental species mixtures. It is a nitrogen fixing species. At the same time, it grows tall and forms a dense canopy of sun-leaves that out-shade most competitors. Obviously, maintaining high yielding grasslands with few species requires additional management (Buchgraber and Grindl 2004).

\section{Forests}

Relations between forest growth and tree diversity are difficult to assess because, in many studies only stand volumes and not growth are documented, and the main species of the canopy and not all species are recorded. Therefore, we restrict our analysis to temperate zone central European forests where all data are available.

The relation between stand growth and tree diversity for a regional study in Romania and Germany (Bouriaud et al. 2016) based on grid-based inventory of $1000 \mathrm{~m}^{2}$ plots in Picea abies and Fagus sylvatica-dominated forests shows for the average of all data no response of growth with increasing tree species number (Fig. 4, lower response line). However, there is a significant decrease of the maximum productivity with increasing tree species number of about $10 \%$ with each additional tree species (Fig. 4, upper response line). Since this is an observational study, the decrease could also be caused by variations of site conditions with respect to nutrition and water supply. Generally, in temperate Europe poor site conditions have more open canopies and thus contain more species at lower productivity. The highest

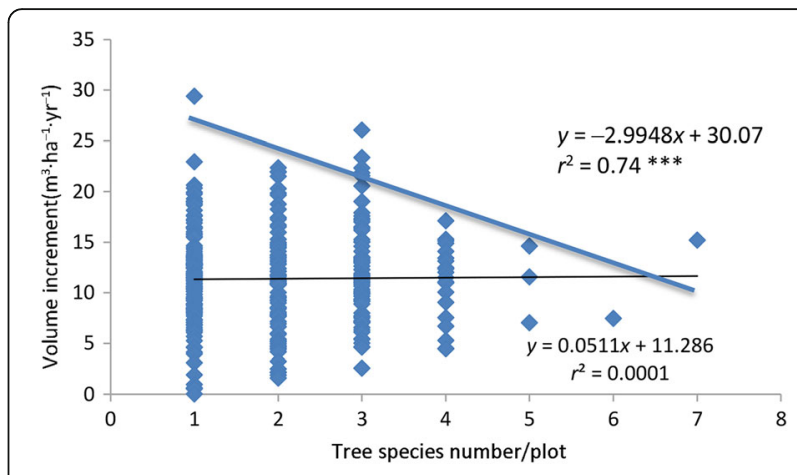

Fig. 4 Growth of managed age class coniferous and deciduous forest in Thuringia, Germany, and Boisoara, Romanian as related to tree species number (Bouriaud et al. 2016). The lower vertical line and equation describes the average change of volume increment with tree species number while the upper blue line and equation describes the change of volume increment with tree diversity of the single highest value at each level of diversity

observed productivity is a monoculture of Picea abies in Germany at $30 \mathrm{~m}^{3} \cdot \mathrm{ha}^{-1} \cdot \mathrm{yr}^{-1}$. Fagus sylvatica monocultures reach only $40 \%$ of the productivity achieved by Picea. The second highest value of productivity is found in a 3 species mixture with $>90 \%$ spruce and $<10 \%$ Betula and Sorbus. The most productive mixture including Fagus and Picea is also a 3 species mixture with Sorbus as additional species, but this mixture reaches only about $60 \%$ of maximum productivity. Apparently, the grid-based inventory shows various mixture effects but no over-yielding. The closer inspection of the diversity effects indicates that the sheer number of tree species does not reflect the level of mixture, which may be biologically important. The distribution of observations in Fig. 4 shows a maximum with monocultures and an exponentially decreasing number of plots with increasing tree species numbers. The observation of decreasing productivity capacity with increasing mixtures is confirmed by a biodiversity experiment of Van der Plas et al. (2016a) who compared European forest types and found the highest levels of ecosystem functions related to production for monocultures of Picea abies. Also results from long-term experimental plots similarly concluded to a higher maximum productivity in monocultures of Picea abies in deciduous temperate forests (Pretzsch, 2009). More generally though, tree species diversity can promote the simultaneous delivery of multiple ecosystem functions. The so-called "Jack-of-all-trades" effect in European forests generates a low level of functioning in highly diverse forest stands (Van der Plas 2016b).

The observations at regional scale are confirmed by the National Forest Inventory of Germany. There is no effect of tree diversity on average tree volume increments, but the upper border line of the data shows a steady decrease with tree diversity of about $8 \%$ (Fig. 5). 


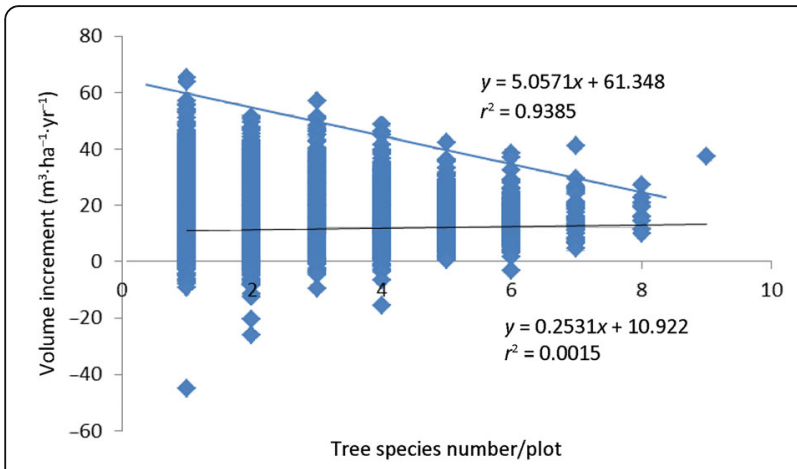

Fig. 5 Growth of forests in Germany based on data from the National Forest Inventory (BWI 3: https://www.forstwirtschaft-in-deutschland.de/ forstwirtschaft/bwi3/) encompassing 52,263 datasets. The lower vertical line and equation describes the average change of volume increment with tree species number while the upper blue line and equation describes the change of volume increment with tree diversity of the 10 highest values at each level of diversity. Positive numbers indicate an increase in stand volume over the repeated inventory over 10 years, while negative numbers indicate a loss in stand volume, mainly by harvest

Similar to the study at regional scale, increasing species numbers are associated with site conditions, mainly water limitations. The highest growth rate was reached in monocultures of Picea abies.

The inventory study in a temperate European forest reached 9 tree species per inventory plot as highest level of tree diversity on $1000 \mathrm{~m}^{2}$ plots. We would expect that this number would be higher in East Asia or North America having higher regional tree diversity (Schulze et al. 2015). In order to make sure that the tree species number reached in Figs. 3 and 4 is representative, we analyzed the data of Schall et al. (2017) on 1 ha plots in the same region of Germany, but confined to deciduous forest (See Additional file 1: Figure S3). This study reached 8 tree species as maximum tree diversity. Thus, the small inventory plots and the relatively low level of tree diversity are representative for European forests.

In the regional study and in the national inventory, stand volumes reached highest levels with monocultures of Picea abies (Fig. 6). In order to discard the possibility that the highest volumes were only reached by management, we included data from Nera, an old National Park in Romania (presently named as Semenik), for which only volume data exist, and it can be seen that highest volumes were reached also in the case of a national parks with monocultures of Fagus sylvatica (Turcu 2012).

Apparently, in forests, tree diversity is maintained either by disturbances, including human management (Reich et al. 2001; Schulze et al. 2009), or by open canopies when environmental conditions are limiting, and it could be both, namely that NPP determines diversity (Reich et al. 2001) or that species composition determines NPP (Schulze et al. 2009).

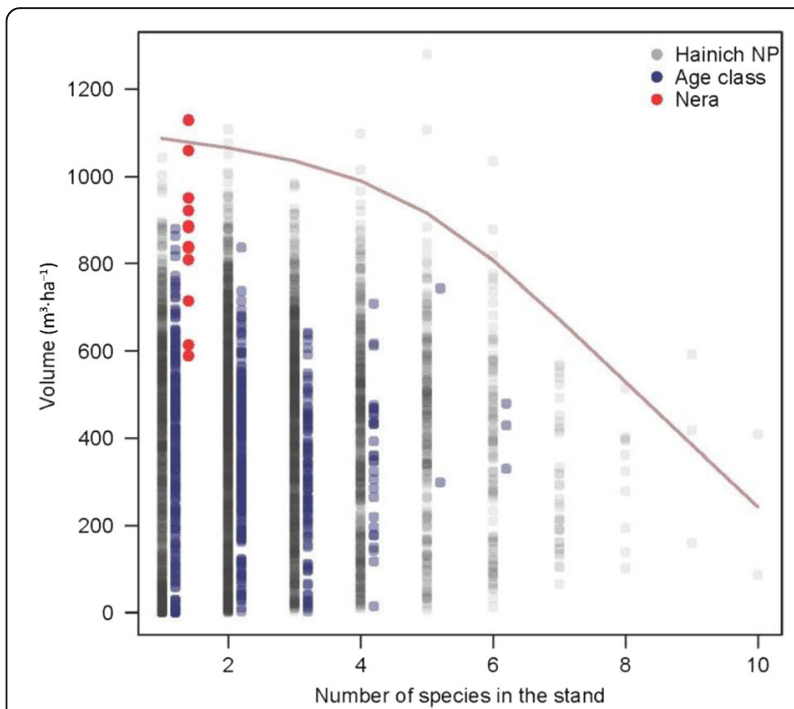

Fig. 6 Stand volumes as related to species numbers in age class forests of Picea and Fagus dominated stands in Germany, and of the national Parks Hainich in Germany and Nera in Romania

\section{Global biodiversity data}

The most comprehensive assessment of growth and tree diversity was made by Liang et al. (2016) who observe, after filtering a large global dataset, that productivity increased with biodiversity (Fig. 7). The maximum rates of growth are fairly low, when compared to the growth rates shown in Fig. 5. The biodiversity/productivity relationship reached an asymptote at $8 \mathrm{~m}^{3} \cdot \mathrm{ha}^{-1} \cdot \mathrm{yr}^{-1}$ which is only $13 \%$ of the maximum shown in Fig. 5 for temperate forest. Figure 7 also includes managed monocultures of specific high yielding species growing in temperate and tropical climates. These monocultures reach growth rates which are far beyond the growth level of the most diverse natural stands, and which are higher than the maximum rates of managed forests in Europe. In fact, these data indicate that the natural vegetation of Europe, which assembled more or less by chance after the Pleistocene, has not reached its growth potential.

It is of interest to note that the full dataset of Liang et al. (2016) shows a distinct peak at low and at intermediate diversity (see Additional file 1: Figure S2). The full dataset apparently contains a mixture of volumes and growth rates and thus remains difficult to interpret. Nevertheless, it remains interesting to see that an envelope function (of volumes) would decline with diversity, indicating reduced stand growth with increasing diversity. There appears to be a second lower peak at intermediate diversity.

\section{Conclusions}

The data indicate that the maximum growth rate of specific monocultures and mixtures is higher than the average diversity effect on productivity. This may be taken as 


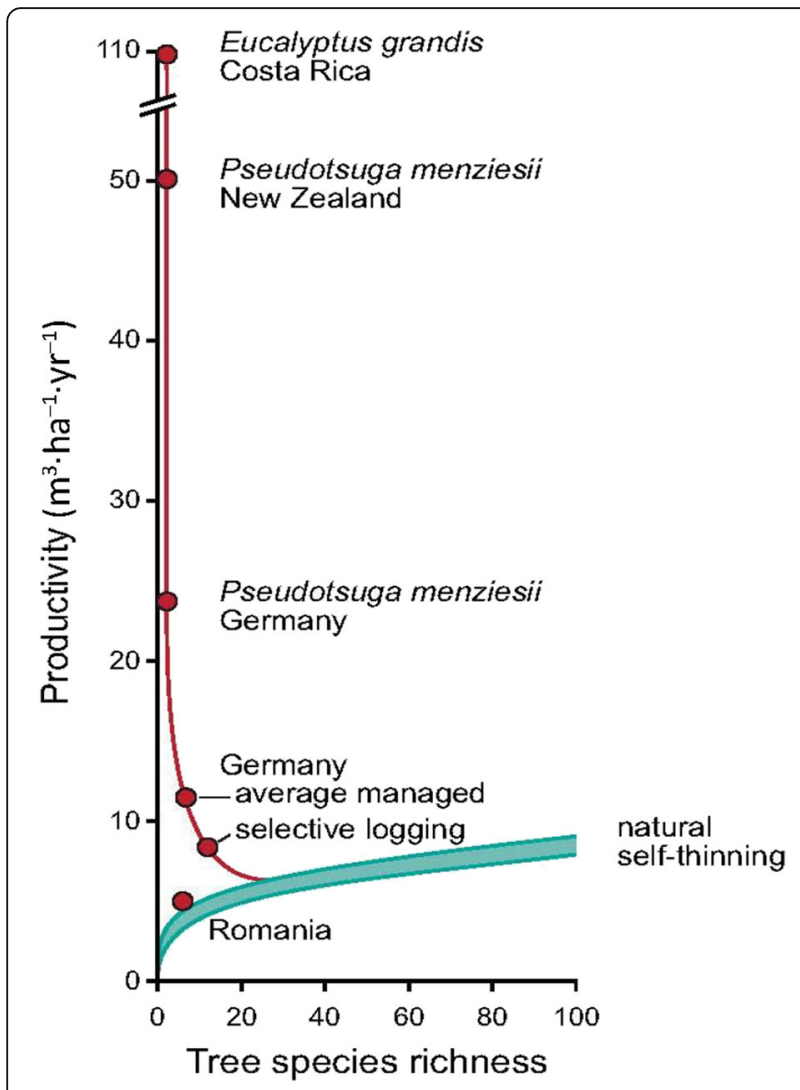

Fig. 7 Forest productivity as related to tree species richness based on a global survey (Liang et al. 2016) and productivity of a selection of fast growing monocultures (Liang et al. 2016, supplement)

the main incentive of land-users to using monocultures. In forests the loss in maximum productivity is about $10 \%$ for each added species, and this is less than the potential gain of average productivity in a random mixture. Highly productive monoculture-trees are also very strong competitors (e.g. Picea and Fagus) and keeping admixture species alive requires frequent interventions by management.

Food industry and bio-economy are additional strong drivers for monocultures because of a demand for a uniform supply of substrate wanted for uniform products. This is even true for forestry, where saw mills are specialized to use specific tree species only. Thus, from the economic side there are few incentives to promote species mixtures.

Opposite to the incentives for monocultures in managed systems, there are also ecological incentives for species mixtures, especially in long-lived forests. A mixture of species results in reduced risk against environmental extreme events (wind-throw) and diseases (insects). It also buffers the temporal variations of climate on productivity (Jucker et al. 2014; Isbell et al. 2015). Thus, in temperate forests, a species mixture is anticipated in modern forestry, but the level of mixture is generally low.
Estimates of the cost of losses of species cannot be based on the average growth/biodiversity function, neither at global nor at local scale, but must contain the fact, that management will select the most productive species or species combination, which produce biomass beyond the level of the growth/biodiversity function.

This study does not intend to clarify the ultimate causes for correlations between NPP and biodiversity or NPP and biodiversity, but to point out that by management NPP can be increased beyond the level offered by natural mixtures of species.

\section{Additional file}

Additional file 1: Figure S1. Distribution of areas with plant species diversity > 2500/pixel, matching the global diversity hotspots. Figure S2. Volume growth versus tree diversity on 1 ha plots of Fagus sylvatica in Thuringia, Germany (Schall et al. 2017). Figure S3. Full dataset of the Liang et al. (2016) database of productivity $(P)$ and tree species richness $(S)$, and the extracted productivity/diversity relationship. The very large values of $P$ indicate that these data may be stand volumes rather than growth rates. The analysis of Liang et al. is driven by a very large number of plots of low productivity at low diversity. (ZIP $667 \mathrm{~kb}$ )

\section{Acknowledgements}

We like to thank Prof Dr. Alexandra Weigelt, Dr. Anne Ebeling, Dr. Tina Buchmann for making the grassland dataset available. These data were collected in the context of the Jena Experiment with Prof. Dr. Nico

Eisenhauer, Prof. Dr. Wolfgang Weisser, and Prof. Dr. Berhard Schmid as PIs, and we thank these persons for maintaining this project. We thank Uli Pruschitzki and Lulian Iulian Dănilă for organizing the forest inventories.

\section{Authors' contributions}

EDS: wrote the 1st draft and all revisions of this paper, OB: analyzed the Romanian forest inventory date, UW: developed the global analysis of NPP vs. biodiversity, CR: analyzed the grassland data, DH analyzed the German forest inventory data, FK contributed the data of the German national forest inventory; PS made statistical analyses; FK supplied the data of the German National Forest Inventory. All authors jointly discussed this broad dataset, and agreed to the final version.

\section{Competing interest}

The authors declare that they have no competing interest.

\section{Author details}

${ }^{1}$ MPI Biogeochemistry, Box 100164, 07701 Jena, Germany. ${ }^{2}$ National Forest Inventory, National Research and Development Institute for Forestry INCDS, Eroilor Bd. 128, Voluntari, Romania and University Stefan cel Mare of Suceava, 13 Universitati Str, 720229 Suceava, Romania. ${ }^{3}$ UFZ, Hemholtz Centre for environmental Research, Physiological Diversity, Permoserstr. 15, 04318 Leipzig, Germany. ${ }^{4}$ Forstamt Schmalkalden, Thueringen Forst, Schlossberg 11, 98574 Schmalkalden, Germany. ${ }^{5}$ Thünen-Institut für Waldökosysteme, Adolf Möller Str 1, 16225 Eberswalde, Germany. ${ }^{6}$ Department Silviculture and Forest Ecology of the Temperate Zones, University of Göttingen, D-37077 Göttingen, Germany.

Received: 7 August 2017 Accepted: 14 December 2017

Published online: 24 January 2018

\section{References}

Bouriaud O, Marin G, Bouriaud L, Hessenmöller D, Schulze ED (2016) Romanian legal management rules limit wood production in Norway spruce and beech forests. Forest Ecosystems 3:20

Buchgraber K, Grindl G (2004) zeitgemäße Grünlandbewirtschaftung. Stoker Leopold Verlag, Germany 
Buchmann T, Schumacher J, Ebeling A, Eisenhauer N, Fischer M, Gleixner G, Hacker N, Lange N, Oelmann Y, Schmidt B, Schulze ED, Weigelt A, Weisser WW, Roscher C (2017) Connecting experimental biodiversity to real-world grasslands. Perspect Plant Ecol (in review)

Cramer W, Bondeau A, Woodward Fl, Prentice IC, Betts RA, Brovkin V, Cox PM, Fisher V, Foley JA, Friend AD, Kucharik C, Lomas MR, Ramankutty N, Sitch S, Smith B, White A, Young-Molling C (2001) Global response of terrestrial ecosystem structure and function to $\mathrm{CO}_{2}$ and climate change: results from six dynamic global vegetation models. Glob Chang Biol 7:357-373

Ellis EC, Antill EC, Kreft H (2012) All is not loss: plant diversity in the anthopocene. PLoS One 7(1):e30535 https://doi.org/10.1371/journal.pone.0030535. Accessed 12 Sep 2017

Hector A, Schmid B, Beierkuhnlein C, Caldeira MC, Diemer M, Dimitrakopoulos PG, Finn JA, Freitas H, Giller PS, Good J, Harris R, Högberg P, Huss-Danell K, Joshi J, Jumpponen A, Körner C, Leadley PW, Loreau M, Minns A, Mulder CPH, O'Donovan G, Otway SJ, Pereira JS, Prinz A, Reas DJ, Scherer-Lorenzen M, Schulze E-D, Siamantziouras A-SD, Spehn EM, Terry AC, Troumbis AY, Woodward Fl, Yachi S, Lawton JH (1999) Plant diversity and productivity experiments in European grasslands. Science 286:1123-1127

Hilger T, Lewandowski I, Winkler B, Ramsperger B, Kageyama P, Colombo C (2015) Seeds of change - plant genetic resources and people's livelihood. INTECH 5: 123-146 http://creativecommons.org/licences/by/3.0. Accessed 12 Sep 2017

Isbell F, Craven D, Connolly J, Loreau M, Schmid B, Beierkuhnlein C, Bezemer TM, Bonin C, Bruelheide H, De Luca E, Ebeling A, Griffin JN, Guo Q, Hautier Y, Hector A, Jentsch A, Kreyling J, Lanta V, Manning P, Meyer ST, Mori AS, Naeem S, Niklaus PA, Polley HW, Reich PB, Roscher C, Seabloom EW, Smith MD, Thakur MP, Tilman DT, Tracy BF, Van Der Putten WH, Van Ruijven J, Weigelt A, W Weisser WW, Wilsey B, Eisenhauer N (2015) Biodiversity increases the resistance of ecosystem productivity to climate extremes. Nature 526:574-577

Jucker T, Bouriaud O, Avacaritei D, Coomes DA (2014) Stabilizing effects of diversity on aboveground wood production in forest ecosystems: linking patterns and processes. Ecol Lett 17(12):1560-1569

Liang J, Crowther TW, Picard N, Wiser S, Zhou M, Alberti G, Schulze ED, McGuire A, Bozzato F, Pretzsch H, de-Miguel S, Paquette A, Hérault B, SchererLorenzen M, Barrett C, Glick H, Hengeveld G, Nabuurs GJ, Pfautsch S, Viana H, Vibrans AC, Ammer C, Schall P, Verbyla D, Tchebakova N, Fischer M, Watson JV, Chen HH, Lei X, Schelhaas M, Lu H, Gianelle D, Parfenova E, Salas C, Lee E, Lee B, Kim H, Bruelheide H, Coomes D, Piotto D, Sunderland T, Schmid B, Gourlet-Fleury S, Sonké B, Tavani R, Zhu J, Brandl S, Vayreda J, Kitahara F, Searle EB, Neldner V, Ngugi M, Baraloto C, Frizzera L, Bałazy R, Oleksyn J, Zawiła-Niedźwiecki T, Bouriaud $O$, Bussotti F, Finér L, Jaroszewicz B, Jucker T, Valladares F, Jagodzinski A, Peri P, Gonmadje C, Marthy W, O'Brien T, Martin E, Marshall A, Rovero F, Bitariho R, Niklaus P, Alvarez-Loayza P, Chamuya N, Valencia R, Mortier F, Wortel V, Engone-Obiang N, Ferreira L, Odeke D, Vasquez R, Lewis S, Reich P (2016) Positive biodiversity-productivity relationship predominant in global forests. Science 354:196-208

Loreau M, Hector A (2001) Partitioning selection and complementarity in biodiversity experiments. Nature 412:72-76

Pretzsch H (2009) Diversity and productivity in forests. In: Scherer-Lorenzen M, Körner C, Schulze ED (eds) (2005) Forest diversity and function, Ecological Studies, vol, vol 176. Springer, Heidelberg, pp 41-64

Reich PB, Bakken P, Carlson D, Frelich LE, Friedmann SK, Grigal DF (2001) Influence of logging, fire, and forest type on biodiversity and productivity in southern boreal forests. Ecology 82:2731-2748

Schall P, Gossner MM, Heinrichs S, Fischer M, Boch S, Prati D, Jung K, Baumgartner V, Blaser S, Böhm S, Buscot F, Daniel R, Goldmann K, Kaiser K, Kahl T, Lange M, Müller J, Overmann J, Renner SC, Schulze ED, Sikorski J, Tschapka M, Türke M, Weisser WW, Wernheuer B, Wubet T, Ammer C (2017) The impact of even-aged and unevenaged forest management on regional biodiversity of multiple taxa in European beech forests. J Appl Ecol https://doi.org/10.1111/1365-2664.12950

Schmidt B, Hector A, Daha P, Loreau M (2008) Biodiversity effects and transgressive overyielding. Plant Ecol 1:95-102

Schulze ED, Hessenmöller D, Knohl A, Luyssaert S, Boerner A, Grace J (2009) Temperate and boreal old-growth forests: how do their growth dynamics and biodiversity differ from young stands and managed forests? Ecol Stud 207:343-366

Schulze ED, Aas G, Grimm GW, Gossner MM, Walentowski H, Ammer C, Kühn I, Bouriaud O, von Gadow K (2015) A review on plant diversity and forest management of European beech forest. Eur J Forest 135:51-67. https://doi. org/10.1007/s10342-015-0922-y
Schulze ED, Beck E, Buchmann N, Clemens S, Müller-Hohenstein K, Scherer-Lorenzen M (2017) Plant ecology. 2nd edition, Springer Verlag, Heidelberg (in print)

Tilman D, Wedin D, Knops J (1996) Productivity and sustainability influenced by biodiversity in grassland ecosystems. Nature 379:718-720

Turcu DO (2012) Cercetări privind dinamica structurii făgetelor virgine şi a mortalității arborilor din Rezervația Naturală "Izvoarele Nerei" / research on the structural dynamics of virgin beech forests and mortality of trees in the "Izvoarele Nerei" nature reserve. PhD thesis, University Braşov, Transilvania, p 156

Van der Plas F, Manning P, Soliveres S, Allan E, Fischer M, Scherer-Lorenzen M, Verheyen K, Wirth C, Zavala M, Ampoorter E, Baeten L, Barbaro L, Bauhus J, Benavides R, Benneter A, Bonal D, Bouriaud O, Bruelheide $H$, Bussotti $F$, Carnol M, Castagneyrol B, Charbonnier Y, Coomes D, Coppi A, Bastias CC, Dawud SM, Wandeler HD, Domisch T, Finér L, Gessler A, Granier A, Grossiord C, Guyot V, Hättenschwilery S, Jactel H, Jaroszewicz B, Joly F, Jucker T, Koricheva J, Milligan H, Mueller S, Muys B, Nguyen D, Pollastrini M, Ratcliffe S, Raulund-Rasmussen K, Selvi F, Stenlid J, Valladares F, Vesterdal L, Zielinski D, Fischer M (2016a) Biotic homogenization can decrease landscape-scale forest multifunctionality. Proc Natl Acad Sci 113(13):3557-3562. https://doi.org/10. 1073/pnas.1517903113

Van Der Plas F, Manning P, Allan E, Scherer-Lorenzen M, Verheyen K, Wirth C, Zavala MA, Hector A, Ampoorter E, Baeten L, Barbaro L, Bauhus J, Benavides R, Benneter A, Berthold F, Bonal D, Bouriaud O, Bruelheide H, Bussotti F, Carnol M, Castagneyrol B, Charbonnier Y, Coomes D, Coppi A, Bastias CC, Dawud SM, De Wandeler H, Domisch T, Finér L, Gessler A, Granier A, Grossiord C, Guyot V, Hättenschwiler S, Jactel H, Jaroszewicz B, Joly F, Jucker T, Koricheva J, Milligan H, Müller S, Muys B, Nguyen D, Pollastrini M, RaulundRasmussen K, Selvi F, Stenlid J, Valladares F, Vesterdal L, Zielínski D, Fischer M (2016b) Jack-of-all-trades effects drive biodiversity-ecosystem multifunctionality relationships in European forests. Nat Commun 4:7. https://doi.org/10.1038/ ncomms 11109

Weisser WW, Roscher C, Meyer ST, Ebeling A, Luo GJ, Allan E, Bebler H, Barnard RL, Buchmann N, Buscot F, Engels C, Fischer C, Fischer M, Gessler A, Gleixner G, Halle S, Hildebrandt A, Hillebrand $H$, de Kroon H, Lange M, Leimer S, Le Roux X, Milcu A, Mommer L, Niklaus PA, Oelmann Y, Proulx R, Roy J, Scherber C, Scherer-Lorenzen M, Scheu S, Tscharntke T, Wachendorf M, Wagg C, Weigelt A, Wilcke W, Wirth C, Schulze ED, Schmid B, Eisenhauer N (2017) Biodiversity effects on ecosystem functioning in a 15-year grassland experiment: patterns, mechanisms, and open questions. Basic Appl Ecol 23:1-73

West PC, Gibbs HK, Monfreda C, Wagner J, Barford CC, Carpender SR, Foley JA (2010) Trading carbon for food: global comparison of carbon stocks vs crop yields on agricultural land. PNAS 107:19645-19648

\section{Submit your manuscript to a SpringerOpen ${ }^{\mathcal{O}}$ journal and benefit from:}

- Convenient online submission

- Rigorous peer review

- Open access: articles freely available online

- High visibility within the field

- Retaining the copyright to your article

Submit your next manuscript at $>$ springeropen.com 